\title{
Construcción social del paisaje
} de los pescadores en Puntarenas, Costa Rica

Recibido: 06/09/2015 · Aceptado: 26/11/2015

Allen Cordero Ulate Universidad de Costa Rica

\section{Resumen}

Se aborda el tema de los paisajes de la pesca a partir de cuatro relatos de pescadores seleccionados en el Barrio el Carmen, Puntarenas, Costa Rica. El paisaje que se ha ilustrado es una mezcla de puerto con mar. El agua en sus inmensidades y riquezas alimenticias. Los primeros paisajes relatados eran de algún modo de costa desde un mar cercano; es decir, desde las lanchas de madera divisando las islas del golfo y la costa de Puntarenas. El modo de producción ha alterado el paisaje, a medida que la pesca ha escaseado, el paisaje, la abundancia y el estilo de vida son objeto de añoranza para los pescadores.

Palabras clave: Construcción social del paisaje, paisajes de pescadores, paisajes de Puntarenas.

*Correo electrónico: allen.cordero@ucr.ac.cr 


\title{
Construction of fishermen's social landscape in Puntarenas, Costa Rica
}

Allen Cordero Ulate Universidad de Costa Rica

\begin{abstract}
The study approaches the subject of fishing landscapes based on the narrations of four selected fishermen of Barrio el Carmen, Puntarenas, Costa Rica. The landscape that is presented is a mixture of port and sea; water and its immensities and food richness. The first landscapes described were in some way coastal landscapes from a nearby sea; that is, landscapes from wooden boats looking at the gulf islands and coast of Puntarenas. The mode of production has modified the landscape. As fishing has diminished, the landscape abundance and life style has become the fishermen's yearning.
\end{abstract}

KeY worDs: Social construction of landscape, fishermen's landscapes, Puntarenas landscapes.

*E-mail: allen.cordero@ucr.ac.cr 


\section{Conceptos básicos y metodología}

El marco teórico del presente artículo ha sido delimitado en el texto "Paisajes y relatos de vida. Apuntes para la interpretación de los paisajes socio-culturales con mención a Puntarenas y Limón (centro) en Costa Rica”, de mi autoría, y que ha servido como perspectiva teórica del proyecto Centros Históricos del Turismo: Puntarenas y Limón, ejecutado por la Escuela de Sociología de la Universidad de Costa Rica junto con las sedes del Pacífico y el Caribe de esta misma universidad (Cordero Ulate, 2014). Este proyecto inicialmente se orientó a estudios del mercado laboral turístico en los distritos centrales de las cabeceras de las provincias mencionadas -que fue donde el turismo se desarrolló originalmente en Costa Rica-, y, a partir de 2013, ha buscado indagar sobre la construcción social del paisaje en articulación con el turismo. Como se sabe, el paisaje constituye un recurso de primer orden en la realidad del turismo, lo cual también es válido para el caso de estos destinos.

\section{Conceptos básicos}

En el artículo mencionado se exponen los siguientes conceptos básicos articuladores: se propone que si bien el paisaje es un dato de la geografía, en su conformación concurre un conjunto de elementos siempre en movimiento; la propia materia, el modo de producción que se asienta sobre el espacio geográfico a través de la historia cambiante. También intervienen en su configuración factores de la acción social, como las propias luchas sociales tendientes a modificar o transformar los modos de producción y sus consecuencias socioculturales. El paisaje, finalmente, es vivido por los grupos sociales y por los individuos, por ende, se le reconstruye de manera constante. Por tanto, al paisaje se le reconstruye y percibe no solo en el trabajo, sino también en la vida cotidiana. Asimismo, el paisaje es una experiencia subjetiva, vivida en una permanente dialéctica entre la enajenación y la liberación. El paisaje vivido por la persona individual es al mismo tiempo objetivo y subjetivo. Objetivo, pues el trabajo y la lucha social son categorías objetivas, pero que al mismo tiempo se les experimenta subjetivamente. De forma que, por ejemplo, a la explotación puede en ciertas circunstancias y en espacios particulares percibírsele como "placentera"; tal puede ser el caso de un trabajador cuando compara su situación con la de un desempleado. 
En particular se tiene en cuenta un texto clásico del paisaje: Antropología del paisaje, climas y culturas y religiones, de Tetsuro Watsuji (publicado en 1937 como primer capítulo de su Ética, y citado en el presente artículo de acuerdo con la edición en español de 2006), en donde se defiende una perspectiva determinista del paisaje en el desarrollo cultural y en concreto de la persona humana. Desde la filosofía existencialista de corte heideggariana de la que parte Watsuji, nos encontramos con nosotros mismos en correlación existencial con el clima y el paisaje (Watsuji, 2006, p. 28).

El otro extremo a esta posición ha sido expresado por Alain Roger en Court traité du paysage (de 1997, citado en el presente texto de acuerdo con la edición en español Breve tratado del paisaje, de 2007), para quien el paisaje es una creación de la cultura y fundamentalmente del arte. Así, la naturaleza no se imita sino que se le recrea, ni tampoco es una especie de madre fértil, sino que el ser humano pasa dándole vida mediante su inteligencia y las creaciones culturales. Por ejemplo, el arte inventó la neblina, y nadie le ponía atención a la neblina hasta que el arte la inventó. El proceso de inventar artísticamente a la naturaleza, a partir de una palabra procedente de Montaigne: "artealizar la naturaleza" (Roger, 2007, p. 21).

Desde la perspectiva interdisciplinaria, vale destacar el libro La construcción social del paisaje, editado por Juan Nogué (2007), que recoge las contribuciones del Seminario Internacional sobre Paisaje, realizado en el otoño de 2004 y 2005. Para Nogué, “el paisaje puede interpretarse como el resultado de una transformación colectiva de la naturaleza y como la proyección cultural de una sociedad en un espacio determinado" (2007, pp. 11-12).

Pasando de manera más directa al terreno de la sociología, puede proponerse que las clases y grupos sociales que se estructuran en el marco del modo de producción son los que socialmente modelan el paisaje. Por una parte, los grupos dominantes darán forma a sus proyectos económicos bajo la modalidad de "planes de desarrollo", que serán sus propuestas de políticas para agenciar sus intereses económicos. Por otra parte, las clases o grupos sociales a los que se les coloca en posiciones de desventaja en el marco del modo de producción no son fatalmente determinados por la exclusión, sino que al mismo tiempo han echado mano de recursos de lucha social o movimientos sociales para defenderse y resistir a ubicaciones espaciales específicas derivadas de las desigualdades sociales. De manera que, históricamente, se ha asistido a luchas sociales 
redistributivas del excedente. Es decir, aquellas vinculadas con la redistribución del excedente generado por disputas en torno al valor de la fuerza de trabajo. Incluso estas luchas tienen impactos paisajísticos, pues dependiendo del valor de la fuerza de trabajo se puede o no acceder a ciertas viviendas y vecindarios, así como a determinada calidad de transportes y servicios públicos.

El paisaje además se construye y recrea en el contexto de la vida cotidiana. En el marco teórico al que se viene haciendo referencia se entenderá como vida cotidiana la que se realiza principal, aunque no exclusivamente, en el orden individual y/o familiar y cuyo lugar de realización es el ámbito privado de las viviendas. Puede agregarse a esta definición la vida que se manifiesta en los barrios, ciudades o también pequeños pueblos rurales o semirrurales, pero que no se trata de acción colectiva consciente, sino más bien de acciones de rutina de vida, como compras, uso de servicios variados, peluquerías, tiendas de abarrotes, servicios de salud y diversión, entre otras.

El paisaje es finalmente biografía, o sea, historia personal. Hemos postulado a lo largo de los párrafos anteriores que el paisaje se hace social e históricamente. No nos vamos a desdecir. Simplemente se puede agregar que la historia social también se expresa en multiplicidad de biografías personales, que vienen a concretar la historia colectiva. Es cierto que la historia social no equivale a la suma de las historias individuales, pero hacen parte y se reflejan dialécticamente en la historia general.

El trabajo, las acciones colectivas y la vida cotidiana, como se dijo antes, van construyendo socialmente el paisaje. Se puede postular que lo van configurando a largo plazo. Como el paisaje se manifiesta geográficamente, los cambios que acaecen en su apariencia a veces concurren a lo largo de periodos muy extensos. Puede ocurrir, claro está, que fenómenos ya sea de la naturaleza o del desarrollo social generen cambios bruscos del paisaje.

\section{Metodología}

Las historias individuales podrían inscribirse en el marco de cambios paisajísticos relativamente imperceptibles, que sería cuando pareciera que la historia se ha detenido en ciertos lugares. Pero en el marco del capitalismo podría pensarse que esto no es lo corriente, pues ha sido el modo de producción el que mayores 
y más rápidas modificaciones ha provocado y sigue provocando en el paisaje. Las personas tomadas individualmente, por tanto, se inscriben al mismo tiempo en una historia paisajística como constructores individuales del paisaje, al menos en las dimensiones ya señaladas: trabajo, lucha social y vida cotidiana. Se podrían esperar, entonces, ciertas correspondencias, no necesariamente mecánicas, entre historia social y, en consecuencia, historia del paisaje con trayectorias de vida, por ende, con biografías específicas.

Metodológicamente, lo antes dicho nos lleva a vincular paisaje con historias de vida 0, más en concreto, con relatos de vida. Podríamos denominar este enfoque relatos temáticos de vida, pues el fragmento de experiencia vivida que más nos ha interesado en estos relatos es el de la relación entre individualidad y paisaje. ${ }^{1}$

Se trataría de la relativa coincidencia entre historia social e individual. Al respecto vale destacar la perspectiva etnosociológica, que subraya las coincidencias entre las lógicas sociales y las individuales. Así:

La hipótesis central de la perspectiva etnosociológica es que las lógicas que rigen el conjunto del mundo social o mesocosmos se dan igualmente en cada uno de los microcosmos que lo componen: observando uno solo, o mejor varios de estos microcosmos, y por poco que se logre identificar las lógicas de acción, los mecanismos sociales, los procesos de reproducción y de transformación, se deberían captar al menos algunas de las lógicas sociales del mesocosmos mismo [Bertaux, 2005, p. 18].

Vamos a esperar que la reconstrucción individual del paisaje se exprese en una trayectoria de vida o, en palabras de Bertaux, itinerario biográfico, al menos de las siguientes maneras. De forma más concreta, la investigación de la que aquí se da cuenta se ha basado en la recolección de 22 relatos sobre paisajes socioculturales en Limón y Puntarenas, Costa Rica, procedentes de actores clave de esos lugares. En el caso de Puntarenas, los subtemas paisajísticos han sido el de la pesca y el transporte, mientras que en el de Limón han sido los paisajes étnicos, los del ocio y la recreación, los del mercado central del cantón de Limón y los paisajes portuarios.

${ }^{1}$ Debido a que las trayectorias de vida son tan variadas y multiformes, el relato de vida permitiría centrar las observaciones a partir de un tema, de una categoría o de un supuesto o concepto articulador (Bertaux, 2005, p. 18). 
El presente texto se fundamenta sobre todo en los relatos recogidos directamente por el autor a pescadores seleccionados de Puntarenas. Uno de los pescadores fue referido por una informante clave de la provincia, y los otros tres relatos fueron recolectados en el Parque Mora y Cañas del barrio El Carmen del cantón central de Puntarenas a partir de observar que este era un sitio de reunión habitual de los pescadores.

\section{Presentación de los pescadores}

Los relatos que sustentan la presente investigación centrada en el paisaje vivido por los pescadores de Puntarenas, Costa Rica, fueron brindados por Enrique Sandí (Quique Salsa), Carlos Salas (Esparza), Mario Zamora, y Jorge Gutiérrez (Abuelo). En adelante, nos referiremos a ellos por sus apodos o alias donde corresponda, a excepción de Mario Zamora, quien no lo mencionó. ${ }^{2}$ Ello con el propósito de hacer más agradable nuestra exposición (a menudo los artículos de carácter científico son de una presentación densa) y, además, quienes nos dijeron sus apodos se mostraban muy orgullosos de tenerlos: Quique Salsa, amante de la salsa y quien alegra con su baile los días de trabajo; Esparza, orgulloso de su lugar de origen, y Abuelo, muy contento de haber sido calificado en su contexto como el de más edad.

Excepto en el caso de Mario Zamora, a quien buscamos en su empresa, a los restantes informantes los localizamos en el Parque Mora y Cañas, en el barrio El Carmen, en la punta de Puntarenas. Actualmente, en este parque se congregan desde las seis de la mañana los pescadores de diferentes lugares del cantón a mostrar su disponibilidad para salir a pescar ya sea en viajes largos o cortos 0 a trabajar en lo que sea. Si a las 11 o 12 del día no ha aparecido ninguna chamba, se regresan a sus casas. A otros de los pescadores en algunas ocasiones se les contrata para reparar o confeccionar redes, lo cual realizan ahí mismo en el parque, colocando o dando forma a las redes, dependiendo del tamaño, sea en un sector del parque o a lo largo de uno de los lados de este.

${ }^{2}$ Los pescadores se presentan con sus nombres reales, pues estos relatos no lesionan la intimidad de ninguno de ellos. Además se cuenta con su autorización para utilizar sus nombres verdaderos. 
En el cuadro 1 se presenta un resumen de los datos sociodemográficos de cada informante: edad, ocupación, situación actual, condición social de la familia de procedencia y educación. Finalmente, se indica la fecha en que se hicieron las entrevistas narrativas o relatos.

\section{CUADRo 1. Características sociodemográficas básicas de los informantes}

\begin{tabular}{|c|c|c|c|c|}
\hline \multirow[b]{2}{*}{ Variables } & \multicolumn{4}{|c|}{ Informantes } \\
\hline & $\begin{array}{l}\text { Enrique Sandí } \\
\text { (Quique Salsa) }\end{array}$ & $\begin{array}{l}\text { Carlos Salas } \\
\text { (Esparza) }\end{array}$ & Mario Zamora & $\begin{array}{c}\text { Jorge Gutiérrez } \\
\text { (Abuelo) }\end{array}$ \\
\hline $\begin{array}{l}\text { Edad } \\
\text { (en años } \\
\text { cumplidos) }\end{array}$ & 69 & 52 & 49 & 61 \\
\hline Ocupación & $\begin{array}{l}\text { Pescador y } \\
\text { redero }\end{array}$ & Pescador & $\begin{array}{l}\text { Pescador } \\
\text { comerciante } \\
\text { (actualmente) }\end{array}$ & $\begin{array}{l}\text { Pescador } \\
\text { (cocinero) }\end{array}$ \\
\hline $\begin{array}{l}\text { Situación } \\
\text { actual }\end{array}$ & $\begin{array}{l}\text { Pensionado, } \\
\text { pero va } \\
\text { diariamente al } \\
\text { parque Mora } \\
\text { y Cañas para } \\
\text { ver qué trabajo } \\
\text { aparece, para } \\
\text { ayudarse con la } \\
\text { obligación. }\end{array}$ & $\begin{array}{l}\text { Capitán que } \\
\text { va diariamente } \\
\text { al parque } \\
\text { Mora y Cañas, } \\
\text { esperando que } \\
\text { le contraten. } \\
\text { Pero acepta } \\
\text { cualquier } \\
\text { trabajo, incluso } \\
\text { de "cuechero"4.* }\end{array}$ & $\begin{array}{l}\text { Es dueño de } \\
\text { una empresa } \\
\text { comercializadora } \\
\text { de pescado } \\
\text { y mariscos, } \\
\text { producidos } \\
\text { de maneras } \\
\text { sostenibles. }\end{array}$ & $\begin{array}{l}\text { Pescador-cocinero } \\
\text { que diariamente va } \\
\text { al Parque Mora y } \\
\text { Cañas para ver si } \\
\text { lo contratan. }\end{array}$ \\
\hline $\begin{array}{l}\text { Condición } \\
\text { social de la } \\
\text { familia de } \\
\text { procedencia }\end{array}$ & $\begin{array}{l}\text { De una } \\
\text { familia muy } \\
\text { pobre, debió } \\
\text { abandonar } \\
\text { el colegio. } \\
\text { Trabajaba en } \\
\text { el mercado } \\
\text { halando bolsas } \\
\text { y ya había } \\
\text { trabajado de } \\
\text { limpiabotas. }\end{array}$ & $\begin{array}{l}\text { Nació en } \\
\text { Guanacaste, } \\
\text { pero a los } \\
16 \text { años su } \\
\text { familia emigró } \\
\text { a Puntarenas. } \\
\text { Vivió en Bo. } \\
\text { Fray Casiano; en } \\
\text { un precario. } \\
\text {-Empezó a } \\
\text { los } 16 \text { años } \\
\text { a trabajar } \\
\text { como peón de } \\
\text { construcción. } \\
\text {-A los } 20 \text { años } \\
\text { se hizo pescador } \\
\text { hasta la fecha } \\
\text { actual. }\end{array}$ & $\begin{array}{l}\text { Nació en el Bo } \\
\text { El Cocal, de El } \\
\text { Carmen. } \\
\text {-Papá muellero } \\
\text { y mamá ama de } \\
\text { casa. } \\
\text {-Familia } \\
\text { numerosa de } \\
\text { ocho hermanos. } \\
\text {-Vendía mangos } \\
\text { a los turistas. }\end{array}$ & $\begin{array}{l}\text { Nació en Quepos, } \\
\text { pero migró a } \\
\text { diversos lugares; } \\
\text { Guanacaste y } \\
\text { zona sur donde } \\
\text { trabajó como peón } \\
\text { bananero hasta los } \\
32 \text { años. A partir } \\
\text { de ahí se dedicó a } \\
\text { la pesca. }\end{array}$ \\
\hline
\end{tabular}


CUADRo 1. Características sociodemográficas básicas de los informantes

(finaliza)

\begin{tabular}{ccccc} 
Variables & \multicolumn{2}{c}{ Informantes } \\
& $\begin{array}{c}\text { Enrique Sandí } \\
\text { (Quique Salsa) }\end{array}$ & $\begin{array}{c}\text { Carlos Salas } \\
\text { (Esparza) }\end{array}$ & Mario Zamora & $\begin{array}{c}\text { Jorge Gutiérrez } \\
\text { (Abuelo) }\end{array}$ \\
\hline Educación & $\begin{array}{c}\text { Secundaria } \\
\text { incompleta }\end{array}$ & $\begin{array}{l}\text { Primaria } \\
\text { completa }\end{array}$ & $\begin{array}{l}\text { Hasta quinto año } \\
\text { de secundaria } \\
\text { pues tenía que } \\
\text { trabajar (pescar) }\end{array}$ & $\begin{array}{l}\text { Llegó hasta sexto } \\
\text { grado }\end{array}$ \\
$\begin{array}{l}\text { Fecha de la } \\
\text { entrevista }\end{array}$ & 11.06 .13 & 27.08 .13 & 10.06 .13 & 08.10 .13 \\
\hline
\end{tabular}

*Cuechero: es la denominación más humilde que se le puede dar a un pescador; es el primer eslabón de la formación del pescador donde la remuneración no es en dinero, sino en "cuechas", "cualquier cuecha", o sea, lo que el capitán le quiere retribuir de la pesca, por tanto, pago en especie.

El más joven de los informantes tiene 49 años y el de mayor edad ya casi ronda los 70. En general, como se ve, pescadores con experiencia. Ellos vivieron desde la época de la abundancia de la pesca, donde incluso en el estero se podía pescar, hasta los tiempos de la creciente escasez que se han presentado especialmente en la última década, pero que ha sido un paulatino proceso de agotamiento. Según se aprecia, la situación actual de estos pescadores, excepto la de Mario Zamora, es la de semiempleados, pues son contratados a conveniencia por administradores o dueños de lanchas y barcos.

Las familias de procedencia de estos pescadores se caracterizaron por su pobreza, en algunos casos extrema. Quique Salsa, por ejemplo, nos relató que su mamá provenía de Guanacaste y se asentó en el barrio El Carmen, en una casa que quedaba diagonal a la esquina noroeste del Parque Mora y Cañas (en 2013, la casa aún existía). La mamá fue lavandera de familias elegantes y de profesionistas, como dentistas, médicos e ingenieros, que habitaban en los alrededores del Parque Mora y Cañas. Uno de los nombres mencionados por don Quique fue Rafael París, el ingeniero que diseñó los malecones. El papá de don Quique fue zapatero de toda "esa gente" elegante que habitó por el Parque Mora y Cañas y que ahora ya no vive ahí.

Los informantes tuvieron que trabajar desde muy jóvenes en labores humildes y básicas, propias del Puntarenas urbano que les tocó vivir en sus años de 
infancia o adolescencia, como limpiabotas, peones bananeros o de construcción, o halando bolsas y sacos en el mercado.

Entonces, dada su situación familiar y su temprana incorporación al trabajo, buena parte de los informantes terminó con dificultades la primaria. Solamente Mario Zamora completó la secundaria. De hecho, él presenta una situación socioeconómica muy diferenciada de los demás pescadores, es decir, de prosperidad económica.

Asimismo, Abuelo nos contó detalles de su contexto familiar: "mi mamá en vida no era mi mamá, mi papá en vida no era mi papá. Mi papá era el hermano del que me crió...." ${ }^{3}$

\section{Algunos elementos de la infancia y la juventud}

En este pequeño apartado intentamos rescatar algunas imágenes de la formación de estos pescadores en ciernes, centrados en el aspecto recreativo, es decir, dejando de lado, al menos por el momento, los aspectos duros de la vida, o sea, los del trabajo y las carencias.

Los juegos de los en ese entonces niños se ubicaban entre la tierra y el mar, lo que parecería obvio, dado el contexto geográfico del que estamos hablando. En la tierra sobresalen los juegos urbanos en los parques, las calles y el infaltable futbol. Tal y como nos relata Quique Salsa, quien dice que en el Parque Mora y Cañas, situado justamente en el barrio El Carmen y que todavía es escenario de los pescadores puntarenenses -pues ahí se siguen reuniendo desde las seis de la mañana a esperar si sale alguna chamba, o bien trabajando allí mismo en la reparación o confección de grandes redes de pesca, algunas de las cuales son desplegadas de lado a lado del parque-, en la infancia jugaban quedó hasta 40 niños. Ahí debutó el equipo uva, que jocosamente el informante nos indicó lo que significaba: Unión de Vagos Asociados. Este equipo representaba los alrededores del Parque Mora y Cañas y se enfrentaba en ese entonces al equipo Los Caites, aludiendo a un sector vecino conocido con ese nombre. ${ }^{4}$

${ }^{3}$ Esta cita, y en adelante todas aquellas procedentes de los relatos, salvo indicación contraria, tienen como fuente las transcripciones de las entrevistas realizadas a los informantes indicados.

${ }^{4}$ Hoy en día, en ese sector del barrio El Carmen todavía existen dos famosas marisquerías populares de Puntarenas: El Caite Negro y El Caite Blanco. 
Me contó Quique:

este parque (Mora y Cañas) tenía unas diversiones, bueno, algo único, todavía recuerdo, ahí donde está aquel muchacho, ahí había un tobogán bien largo, bien alto, ahí nos tirábamos en el tobogán para acá en el mismo tobogán más para acasito habían como especie de pasamanos como para que un carajo que hiciera gimnasia y ahí llegaba un muchacho que vivió en unas casitas que habían aquí de madera, él era chiquitito y le gustaba venir a hacer un tipo de gimnasia que ahí había ahí, allá al fondo había una rueda de chicago y había un tipo de balance que ahora hay en ese tipo de parques que lo hacen de una sola pieza, en ese tiempo era una, una tabla de esas tabla de madera pero de madera, ahh, pero bien larga el balanceo, ahh, estaba a la par de la rueda de chicago, aquella esquina ahí donde está la cancha de tenis ahí había un quedó, ahí nos metíamos como 40 a jugar quedó pero no tocar tierra, imagínese qué clase de quedó había, si no tocar tierra si se tocaba tierra entonces se le daba un cocacho pero para quedarlo a uno, imagínese 40 chavalos en ese quedó, imagínese qué clase de quedó ahí, ahh, y por acá había un pocón de hamacas y ahí jugábamos fútbol ahí con ese muchacho patona y el otro que iba con él ahí, ellos vivían en una casita de madera vieja que había ahí, todavía está...

Por su parte, Mario Zamora nos dibuja parte de los hermosos juegos disfrutando del estero, escenario inmediato de los futuros pescadores: "nosotros jugábamos con los botes y todo eso en ese tiempo dedicábamos los tiempos libres, digamos, de escuela y nos íbamos a pescar”. Los niños pescaban en el llamado "barco hundido" en el estero.

En particular, Mario evoca el paisaje nocturno del estero, un paisaje sonoro, el de las corvinas roncando:

Bueno, más que todo el silencio, digamos, de la noche, a veces escuchábamos a la corvinas, uno le llamaba roncar, entonces uno le ponía atención al casco del bote y ahí se escuchaba donde ellas roncaban "rrr" y entonces uno sabía que ahí andaban las corvinas, o qué sé yo, o la frescura de la noche.

En los recuerdos antes indicados prevalecen las imágenes de acción, esto es, los juegos en el Parque Mora y Cañas, los partidos de futbol contra Los Caites, o las escenas de pesca en el barco hundido y las salidas un poco más aventuradas hacia el estero, en especial el paisaje de las corvinas roncando. En el momento actual se evocan como imágenes, incluso puede decirse como imágenes 
paisajísticas, sin que la noción de paisaje aparezca verbalizada. Es la vivencia del paisaje sin su concepto. Esto resulta muy fuerte en la infancia, cuando la acción y el descubrimiento permanente parecen ser la tónica.

\section{Etapas de formación y puestos en la pesca}

De acuerdo con nuestros informantes, hay tres grados, por así decirlo, en la formación de los pescadores: cuechero, marinero y capitán. Éste es el caso de Mario Zamora, quien pasó por las tres etapas. En la de cuechero -algo así como principiante, pues es el primer enganche de un posible aspirante- no hay sistemas de pago, sino generalmente este se hace en especie, por ejemplo: "Una piña de pescado”. En la de marinero -que a Mario le tocó vivir todavía siendo niño a los 11 años- se presupone que la persona conoce de artes de pesca, sabe cocinar, así como gobernar la embarcación. Finalmente, el grado de capitán significa poder gobernar una embarcación de 35 pies, utilizando cartas de navegación -Mario logró este nivel a los 21 años. ${ }^{5}$

Respecto a nuestros informantes, pueden ubicarse, además de pescador a secas, algunos oficios o funciones particulares, como el caso de Quique Salsa, quien es redero, o sea una persona capaz de confeccionar y reparar redes de pescar. Él no desprecia ningún trabajo, ni siquiera el de cuecha. Para mejorar sus ingresos, a menudo ha combinado funciones y trabajos, como los de cuechero y redero, lo que le llevó a aumentar exageradamente sus jornadas laborales, pues mientras no pescaban, él reparaba redes. En total, hasta el momento, Quique Salsa ha sido pescador-redero por cerca de 35 años. Empezó como cuechero. Tiene la experiencia de pesca artesanal, y también la de barco camaronero, como empleado. Él mismo lo ilustra así:

Bueno, diay yo duré de cuecha porque diay a veces ganaba cuando eso más plata que el marinero, pero yo me duplicaba en el trabajo. Como la cuecha era tan abundante había un pescadillo que lo botaban, entonces yo lo cogía y lo fileteaba, vea como los cuartos eran de hielo, entonces había una recamara entonces ahí lo iba guardando, claro, con aquel desvelo y toda aquella cuestión,

${ }^{5}$ Posteriormente, Mario se convirtió en dueño de una embarcación, y cuando sus hijos se hicieron adolescentes y a solicitud de su esposa dejó de pescar, reorientándose a la comercialización de pescados y mariscos, con el propósito de estar cerca de sus hijos. 
como estaba joven entonces uno aguantaba cualquier cosa y terminábamos [hechos] una pelota y en la noche que ya pues supuestamente ya vamos a descansar yo estaba fileteando, el sueño me dominaba pero lo sencitaba ${ }^{6}$ en el sentido de tal vez dormía una horita y ya ese sueño ya está [...] y vuelta y pegue en la mañana en la misma función y entonces como ya empecé yo a travesear [las redes] todos los carajos que fueron saliendo y que se fueron haciendo capitanes entonces me decían eey Quique mae ándate conmigo mae para que me ayudés ahí en las redes de camarón...

En el caso de Abuelo, este es cocinero y a quien se le ve disfrutar profundamente de esa función:

ahí en una lancha, se le dice al capitán hoy voy a hacer una sopa, ¿qué le parece capitán? A los tripulantes no, porque diay, usted es el que manda, porque unos tripulantes dicen yo no como eso [...] agarran poca comida y no se la comen toda, sino que la botan, tampoco eso no. Coman poquito de comida muchachos, si quieren más cogen más porque el cocinero no puede servirle, si uno le sirve mira muy poquito, viera que noo, yo voy a hacer un pescadito frito, una sopita de pescado, esa cochinada no me gusta a mí, ahh ¡maldita mañana! ¿Qué les contesto yo? En tierra aguantan hambre y aquí no quieren comer. Porque uno en tierra aguanta hambre, en tierra uno todos los días no come [...] si yo quiero hacer pescado hoy y me dicen los muchachos, hacés un sopón hoy bien rico, va sopa hoy... a media noche ok si un cachito ahí de merla [marlín], pintito con gallito frito ya lleno y, perdón, el cocinero, si a media noche la tripulación le pide comida hay que cocinar.

En la cita antes expuesta, así como en el relato en su conjunto, puede observarse que, para Abuelo, son fundamentales las relaciones personales en el grupo de pescadores que viajan en la lancha. De manera que parece que en asuntos de comida se debate entre lo que ordene el capitán, lo que disponga él mismo como cocinero, o bien complacer al grupo, pero esto no siempre resulta fácil, pues, si le va bien, su comida puede ser recibida con complacencia, o, cuando las cosas no funcionan, puede ser rechazada, reflejándose en que no quieren comer lo que él prepara. Abuelo valora cuando se dan buenas relaciones personales en el grupo que viaja en la lancha:

6 "Sencitaba", expresión utilizada por Quique Salsa para indicar que pasaba en una especie de duermevela, entre trabajo y escaso descanso. 
La parte bonita en el trabajo de pesca es llevar buen alineamiento con los compañeros, que no haya discordia, que no haya problemas mucho menos con el capitán, cualquier cosa hay que dirigirse con el capitán, él es el que manda, es el que manda, y lo segundo con la costumbre de compañerismo, que haya una unión, nos fuimos tranquilos llegamos tranquilos, usted sabe lo que es venir a tierra con un problema con un tripulante.

De hecho, Abuelo guarda en su memoria un incidente que le sucedió cerca de Ecuador, cuando en viaje de pesca sufrió el acoso sexual de otro compañero, ante lo cual estuvo a punto de cometer un crimen. Si no hubiera sido por la intervención oportuna del capitán, que logró detectar los movimientos de Abuelo cuando sigilosamente en la noche, con cuchillo en mano, se apretaba a atacar a su compañero acostado en otro camarote, quizás Abuelo hubiera culminado su objetivo.

\section{Fiesta en tierra}

Otro rasgo sociocultural de los informantes que dan sustento a esta investigación es su propensión a la fiesta, entendiendo por fiesta las tandas o largas jornadas de alcohol, baile y mujeres una vez llegados a tierra. Parece que entre más prolongada era la salida de pesca, mayor el desquite, la descarga fiestera. Todos ellos, y de nuevo excepto Mario Zamora, exhiben este gusto por el ambiente de puerto, los salones de baile, la música de cantina, a veces muy alegre y a veces triste, dependiendo del estado de ánimo y el momento de la fiesta.

En cuanto a Quique Salsa, como ya se dijo, su alias deriva de su inclinación espontánea para el baile. Él todavía se vanagloria de su capacidad para tomar y no despeñarse, es decir, caer en una tomadera de licor, hundirse en la ingesta alcohólica. Según él, esto se debía a que le gustaba bailar y comer, lo que le permitía procesar mejor las cervezas. En época de Navidad, por ejemplo, no le gustaba la fiesta, más bien andaba pescando, pero cuando en enero regresaba a Puntarenas y traía "buena plata" se iba en una "sola tanda". Sin embargo, como combinaba cerveza con baile y no dejaba de comer, entonces, dice él, manejaba las fiestas: 
a mí no me jodía la goma porque yo en la mañana yo, usted le desayunaba todo normal, también comía hasta repetía doble diay -¿qué me iba a dar goma?- y como en la cantina antes había solo rocola entonces yo con la misma bailada me sacaba el jumo del alcohol de la cerveza que era lo que yo más tomaba entonces yo costaba que me emborrachara porque yo mismo con la bailada solo bailando con las rocolas. Ahí se metía más de una cabra a bailar pero no se daban cuenta que yo botaba la... entonces todo el día me decían que yo andaba tomando que no sabían qué era la cuestión vea... [Y] si me gustaba "chainiar" muy bien combinaba, yo vestía mucho de blanco, tenis blancas, tenis, combinaba muy bien la ropa para vestir, tenía mi "filing" en ese aspecto.

La historia de Esparza es más fuerte. En los buenos tiempos de la pesca tomaba mucho. Aunque estaba casado, después de regresar de viajes de pesca no iba directo para su casa sino que se quedaba parrandeando. De manera que su primera esposa se cansó y "lo divorció". Luego del divorcio vivió 17 años con su mamá. Seguía ganando mucho dinero como pescador pero lo despilfarraba. Hasta que sufrió un accidente de tránsito en estado de ebriedad. Dejó de beber. Ahora tiene seis años de no tomar y se ha vuelto a casar.

Cuando había abundante pesca, en los años ochenta y noventa, Esparza todavía ganaba mucha plata, pero bebía bastante. En una salida de pesca podía obtener hasta siete mil colones, que era mucho dinero, pero gran parte de él era dejado en bares y salones de baile, en invitaciones a amigos y mujeres. Él mismo relata sus gustos de entonces:

En aquel tiempo cuando había pesca salía uno aquí como estaba yo hablando, como siete mil pesos yo compré tele, compré refri, compraba comedera suficiente en aquel tiempo cuando yo comencé, porque la pesca estaba abarrotada y nosotros los pescadores somos un poquito bastante duros de... de cabeza, todo el tiempo pensamos que la pesca iba a estar así y íbamos para allá y veníamos como acá, pedíamos guaro. Puntarenas antes había mucho prostíbulo en todos los lugares trabajaban hasta cinco mujeres y esas mujeres tal vez no era mujeres de ambiente, pero usted las veía estaban paradas a la salida porque eran empleadas y después había mucho prostíbulo, prostíbulo mucho entonces uno desperdiciaba la plata porque diay de

${ }^{7}$ Cabra: mujer.

8 "Chainiar": vestir. 
por sí ahorita salimos y cuando venimos con buena plata, nunca pensamos en una economía y aquí en Puntarenas usted pregunta por muchos pescadores la mayoría y están como yo...

En esta misma sensibilidad fiestera, se expresa Abuelo, como se puede apreciar en el siguiente diálogo entre investigador y relator:

Allen Cordero: ¿De su trabajo cuando salía de pesca qué era lo que más le gustaba? Abuelo: ¡Ah, la diversión!

Allen Cordero: ¿Qué era su diversión?

Abuelo: Las cantinas.

Aunque ya lleva 11 años sin tomar, cuando habla de estos recuerdos su mirada se ilumina con añoranza por aquellas fiestas. Vive como en una especie de contención relativa. En aquellos tiempos de la diversión, dice: "Solo, si encontraba una dama me quedaba con ella, digamos cuatro o cinco en una mesa, por medio de eso teníamos problemas...”.

En una riña callejera, encontrándose borracho, estuvo a punto de perder la lengua; de hecho, le hace falta una parte de ella. Precisamente este accidente fue el que lo llevó a recapacitar y a dejar de tomar:

Un carro me atropelló... hasta la lengua casi la pierdo, casi quedo mudo, me operaron de, una operación, iba a quedar mudo yo... Porque estaba en una cantina de Playas del Coco estaba una mujer y la intentó manosear, entonces me metí, nadie se metía y en eso yo me metí y dije no'mbre no haga eso y yo me le paré, nos agarramos, hace años, estoy con vida gracias a Dios estoy hablando.

En conjunto se ve que nuestros informantes tuvieron mucho gusto por la bebida, las mujeres y las cantinas. Incluso se nota que siguen añorando aquellos años mozos, pero la edad y las experiencias, algunas de ellas al filo de muerte, los ha conducido a una vida abstemia. Al respecto parece que en ellos no hay posibilidad de moderación, de un control gradual, sino que su gusto es por lo extremo, la fiesta sin medida, mientras el cuerpo aguante, o bien, hasta el límite de los recursos económicos. Como en los tiempos en que se daban estos gustos la pesca era abundante y ganaban, a su decir, "buena plata", la fiesta seguía hasta donde el bolsillo aguantara, para después iniciar un nuevo ciclo, en este caso una nueva salida de pesca que los alejara de los "malos pensamientos". 
Debe tenerse en cuenta que mientras estuvieran embarcados no les era permitido tomar.

\section{Tiempos de abundancia y vivencia de los paisajes}

Los relatos de pesca de los informantes se ubican desde los años cincuenta hasta los noventa. Quique Salsa es quien muestra una más temprana experiencia de pesca, justamente a partir de la década de los cincuenta. En el caso de Mario Zamora, aunque es el más joven de los entrevistados, se inició en estas labores a mediados de los setenta; de hecho, como ya se dijo, llegó a ser marinero a los 11 años. En lo que respecta a Esparza, él empezó en los años ochenta, y Abuelo, que, como se vio antes, primero anduvo en variadas ocupaciones, hasta en los noventa se hizo pescador. En el cuadro 2 puede observarse la información correspondiente.

CUAdRo 2. Los primeros años de la pesca; tiempo de la abundancia

\begin{tabular}{|c|c|c|c|c|}
\hline \multirow[b]{2}{*}{ Variables } & \multicolumn{4}{|c|}{ Informantes } \\
\hline & Quique Salsa & $\begin{array}{l}\text { Carlos Salas } \\
\text { (Esparza) }\end{array}$ & Mario Zamora & $\begin{array}{l}\text { Jorge Gutiérrez } \\
\text { (Abuelo) }\end{array}$ \\
\hline $\begin{array}{l}\text { Año(s) } \\
\text { en que se } \\
\text { realizaba } \\
\text { la pesca }\end{array}$ & $\begin{array}{l}\text { Década de los } 50 \\
\text { aproximadamente }\end{array}$ & $\begin{array}{l}1981 \\
\text { aproximadamente }\end{array}$ & $\begin{array}{l}1975 \\
\text { aproximada- } \\
\text { mente }\end{array}$ & $\begin{array}{l}\text { Desde } 1990 \\
\text { aproximadamente. }\end{array}$ \\
\hline $\begin{array}{l}\text { Lugares } \\
\text { para } \\
\text { pescar }\end{array}$ & $\begin{array}{l}\text { Primero frente } \\
\text { a la costa de } \\
\text { Puntarenas } \\
\text { después por toda } \\
\text { la costa, lugares } \\
\text { mencionados } \\
\text { fueron Quepos } \\
\text { y frontera con } \\
\text { Nicaragua. }\end{array}$ & En la angostura. & El estero & $\begin{array}{l}\text { Empezó en la } \\
\text { costa, cerca de } \\
\text { playas del Coco. }\end{array}$ \\
\hline
\end{tabular}

Entre más antiguos los relatos, mayores las historias de abundancia pesquera. Los lugares de la pesca eran muy cercanos al centro de Puntarenas. El estero, ahora sitio reputado por la contaminación, en aquellos tiempos era lugar de abundancia, donde algunos de estos pescadores dieron sus primeros pasos, casi sin saberlo, de manera natural, pues el estero como lugar de recreo se fue haciendo lugar de trabajo, por su gran cantidad de peces y mariscos. Como dice Quique Salsa: 
había tanta abundancia que ahí, bueno, ahí nos íbamos nosotros en aquellos años que había todavía bote, no habían pangas habían botes de piezas que se hacían va, como había tanta madera, pues cualquiera hacía un bote de una pieza, había madera en abundancia, entonces nos íbamos ahí un sábado, un domingo, ya llevamos los limones, todo, la cebolla, lo otro, nada más de ir sacando y hasta la tortilla, ah, para comer el que quisiera comer, sino el plátano ya cocinado porque era tanta la abundancia nada más se metía un poquito uno, pum pum, y ya agarraba 15, 20 [chuchecas] ya las quebraba y ahí pasaba, pasaba el sábado o el domingo...

Y el regreso a tierra firme:

ya nos veníamos en la tarde, a las tres, a las cuatro nos veníamos ahí todavía pegaba cierto viento entonces agarrábamos una rama y se la poníamos al bote entonces veníamos como si fuera una vela con una rama del mismo manglar diay fueron una abundancia y así, y antes no se había rellenado tanto, era muy seco, habían unos bajos que casi la mayoría, siempre se llevaba el bote pero la mayoría cruzaba nadando, porque diay usted cruzaba el bajo y ahí pasaba y ya para llegar al manglar pues era poquito porque estaba tan seco, ahora se rellenó con la cuestión de la construcción del muelle de Caldera...

La imagen de Quique Salsa es muy vívida, uno se puede imaginar los improvisados botes con una rama del manglar funcionando como vela, en la tarde, atravesando el estero de regreso al barrio El Carmen, a los alrededores del Parque Mora y Cañas. Pero él no habla en términos paisajísticos, pues quizás se necesita la mirada exterior que integre los elementos del paisaje. Él habla de historias de su infancia, para lo que la recrea con imágenes del entorno físico.

Quique Salsa platica de sus inicios como pescador en La Angostura, ${ }^{9}$ en este caso su relato está directamente relacionado con la pesca en cuanto actividad económica:

Mario Zamora igualmente testifica ese tiempo de abundancia:

${ }^{9}$ La Angustura se conoce como la pequeña franja más estrecha que separa el mar (Pacífico) del estero y que antiguamente solo permitía el paso de la línea férrea; se ubica a unos seis kilómetros antes de llegar al centro de la ciudad de Puntarenas. Posteriormente, La Angostura, por los rellenos que se le fueron haciendo se fue volviendo más ancha, hasta su conformación actual, con la calle principal que va al centro de Puntarenas. 
Bueno, tal vez la abundancia de pescado que había en ese momento, digamos, este a veces en una sola noche uno podía pescar todo la captura para regresar a la casa, verdad, hubieron momentos en que en una sola noche, digamos, capturamos todo lo que podíamos hacer en tres días, digamos, entonces cuando sucedían esas eran cosas a uno le llamaban a uno mucho la atención.

\section{El tiempo actual: el de la escasez}

Por el contrario, en el contexto actual, concretamente a mediados de 2013, que fue cuando se recogieron estos relatos, prevalece una situación de gran escasez del recurso pesquero. Ahora los pescadores deben alejarse de Puntarenas hasta 1500 kilómetros, en algunas ocasiones llegando a Ecuador o a la Isla del Coco, según los testimonios recabados.

Esparza comenta una escena corriente que les ocurre en las salidas de pesca. En este caso mediante la técnica de pesca en línea, que consiste en una gran línea hasta de 40 millas de largo, de la cual cada cierto espacio caen otras sublíneas donde van atados los anzuelos, unos 2000 en total para esta información. Pues bien, véase lo que les está sucediendo:

la pesca está dura, a veces echa usted un lineazo, 40 millas que echa que 2000 anzuelos y en esos 2000 anzuelos usted saca tal vez unas 15 piecitas que tal vez diez tiburones, un marlín blanco uno rosado, un vela, a veces saca menos usted en 2000 anzuelos, como a veces sale un poquito mejor, a veces pega cinco piezas, tres piezas de tiburón, a veces no pega nada, eso es según el movimiento de luna también y la pesca está decaída, no hay pesca.

Por su parte, Abuelo comparte esta misma apreciación:

Y ahora, en la actualidad, de la pesca estamos muy mal, mal mal mal con todos esos camaroneros que tienen la rastra ${ }^{10}$ todo eso los pescaditos chiquitos miniatura todo eso lo arrolla, todo eso lo mata y el [pesca-

${ }^{10}$ Rastra: pesca de arrastre que consiste en tirar una red hasta al fondo del mar y que va siendo arrastrada o halada por el barco para recoger la máxima cantidad de peces. 
dor] artesanal se queda sin nada, esas panguitas que van al mar de siete de la noche a cinco de la mañana, no traen nada...

Mucho del discurso actual de los pescadores gira en torno a las responsabilidades del agotamiento de la pesca. Es decir, el paso de la abundancia a la escasez tiene que ver con una combinación de factores, entre los que sobresalen:

- La mercantilización capitalista de la pesca, esto es, la presencia de empresas pesqueras grandes que tienen hasta ocho grandes barcos, lo que obviamente eleva como nunca antes las cantidades de captura. Desde este punto de vista se rechaza que la responsabilidad del agotamiento sean los pescadores artesanales, pues estos pescan en las zonas costeras, y se evidencia que la merma de peces no solo se da en la costa sino mar adentro, donde llegan muchos barcos grandes y con modernas técnicas. Las grandes empresas camaroneras que tenían hasta ocho barcos botaban el camarón cuando traían nuevos barcos cargados de camarón.

- El cambio de técnicas de pesca, pues cuando empezó la pesca artesanal las redes eran de dos pulgadas de espesor, pero después se hicieron más finas.

- La capacidad de procesamiento de las plantas camaroneras aumentó, demandando mayores cantidades de camarón.

- Conforme se ampliaban los lugares de pesca aparecieron nuevas especies de camarón, por ejemplo el Fidel, que asimismo fueron capturadas en cantidades industriales, contribuyendo al agotamiento acelerado de esta y otras especies.

- Los pescadores igualmente responsabilizan a lo que denominan "elefantes blancos”, como el Instituto Costarricense de Pesca y Acuicultura (Incopesca), pues también son responsables por no ejercer buena supervisión de cómo se ha pescado.

- Antiguamente los barcos no almacenaban tanto como en tiempos más recientes, ya que no tenían sistemas de refrigeración. Estas naves antes eran de 45 pies, pero las de ahora son de hasta 65-70, lo cual les permite elevar significativamente la cantidad de peces atrapados y su consiguiente almacenamiento. 
- Los "chinos" también son responsables. ${ }^{11}$ De acuerdo con uno de los informantes, ellos "hicieron desmadres" al impulsar la técnica de línea de fondo, y cuando en las neveras ya no quedaba espacio pero pescaban tiburones decían: “¡corten las aletas!”. Solo las aletas porque éstas eran las mejor cotizadas en el mercado.

- Finalmente, algunos de los pescadores son autocríticos y se atribuyen buena parte de la cuota de responsabilidad por las malas prácticas. Por ejemplo, botar al mar una gran cantidad de camarones Fidel que habían sido capturados cerca de Puntarenas, en Herradura, porque se presentaba otra "pelota" de camarones de mejor calidad, y había que dejar espacio en las neveras de la lancha para los camarones más rentables.

\section{Descripciones paisajísticas de la pesca}

No fue fácil entablar conversaciones puramente paisajísticas con nuestros informantes. El concepto paisaje no es de inmediato entendible para estos pescadores. En lo que sí tienen mucho lenguaje, como ha podido observarse, es en lo referente al trabajo; cuando se habla de este o de la cotidianidad en el barrio, o de sus vidas privadas, aparecen variadas imágenes paisajísticas pero sin decir que se está hablando de paisaje. Esto no significa que no sepan qué es paisaje y no puedan aludir a él. Pueden hablar de paisaje pero no extensamente y no como lo haría un especialista en la materia o un artista especializado en paisaje. ${ }^{12}$

Por ejemplo, Esparza nos platica de un paisaje nocturno, por supuesto muy propio de la pesca, pues mucho de esta labor se realiza en la noche:

${ }^{11}$ Se refiere a la Misión Técnica Pesquera de la República de China (Taiwán), que funcionó en el marco del Instituto Nacional de Aprendizaje en los años ochenta y noventa. Buscó mejorar la capacidad productiva de los pescadores artesanales de Puntarenas. El tipo de trabajos que realizó puede verse en Chong (1992). En el estudio de Elisa Li Chan (2013) se ilustra la influencia de esta misión en Puntarenas, en lo que respecta al plano lingüístico.

${ }^{12}$ Incluso se puede pensar que un artista especializado, por ejemplo un pintor o un músico interesado en temas de paisaje, no necesariamente va a tener grandes imágenes verbalizadas de un paisaje, pues su medio expresivo sería la pintura o la música, según fuera el caso. Así, desde una estética hegeliana, los únicos artistas cuyo campo sería la palabra son los poetas. Para el tema que estamos desarrollando este sería el campo de la poesía paisajística. Puede verse al respecto Hegel (1983). 
Ver estrellas entrando y saliendo las estrellas, la oscurana de las nubes, las lucecitas que usted ve una lanchita que va navegando, usted le ve una lucecita roja y el fondeo donde va navegando que es lo que uno ve, las estrellas, alguna estrella que se suelta ahí, shuuuuu, todo eso divisa bien, la noche, es lo que usted ve embarcaciones, claridades, atuneros que tienen un reflejo algún atunero que está, los atuneros tienen mucha luz, son luces filamentos que le llama uno, son luces muy fuertes en el agua se ven los reflejos y estar atento a que tenga usted las luces prendidas del fondeo porque si usted está fondeando durmiendo y deja la luz de fondo y se le quema pasa un mercante, un atunero y usted a oscuras y ahí muere, verdad.

Excelente imagen paisajística esta que hemos reproducido. Se combina amplia perspectiva ya que habla de cómo se ve el cielo nocturno desde la lancha. En cierta forma se trata de una imagen contemplativa del universo. Además, se agrega en la composición un elemento de idealización poética del barco atunero, que refleja sus filamentos en el mar, para después mostrar preocupación por la eventualidad de que la lancha en la que se trabaja no tenga luces ya que un barco mercante la puede golpear y hundirla de inmediato. Puede pensarse que la primera parte de la imagen es contemplativa del cielo nocturno, y que incluso podría ser la experimentada por un turista, sin embargo, en el caso de Esparza, esta da lugar enseguida a una imagen angustiosa por un posible accidente acuático. Esto es una especie de combinación entre contemplación y trabajo. 0 , en otras palabras, de disfrute contemplativo interrumpido por la preocupación de un posible accidente.

Ahora véase la descripción de un paisaje diurno:

es bonito porque usted a veces está y ve los arco iris, viera que los arco iris sí se aprecian en el mar, ipero algo especial!, sí y a veces uno pasa por donde están los arco iris y qué es la composición del arco iris, es agua, usted pasa por un arco iris donde ve usted los colores y ve una llovizna como un sereno, es agua, el agua te da esos colores.

Puede pensarse que aunque se esté en el trabajo, ya sea pescando o viajando hacia los lugares de pesca, hay como una especie de instantes contemplativos del paisaje donde este se aprecia y se disfruta en su conjunto, con visión de perspectiva que es la composición paisajística. Podemos proponer que estos son instantes recreativos o de ocio que se dan en el marco del trabajo. Probablemente 
cuando la labor es muy dura y requiere de mucha acción física y concentración mental para no cometer errores, no hay tiempo para el paisaje, ni para nada más. Pero a veces el trabajo, cualquiera que este sea, alivia las tensiones del individuo y funciona como una suerte de descanso o de aflojamiento mental, muy propicio para el disfrute del entorno. ${ }^{13}$

En una expresión como la siguiente se evidencia por parte de Esparza una gran conciencia paisajística del espacio marino, un gran paisaje acuático: "Usted ahí afuera, usted lo que ve es agua, mar y cielo. Si vuelve a ver arriba lo que usted ve es cielo, si vuelva a ver pa' allá usted lo que ve es agua para el otro lado agua, usted no ve tierra, no ve costa, no ve isla, pura agua”.

Se trata de un disfrute paisajístico utilitario, puesto que se da en el contexto del dominio del trabajo, además es una labor muy dura, muy cansada. Al respecto señala:

Lo que es el espacio, el cielo, las estrellas, esas estrellas fugaces que le llaman, estaba viendo se acuesta uno en la cubierta, estaba mirando pa' arriba cuando usted ve una estrella que se priende ${ }^{14}$ pero con un rabo y usted ve como que caen en el agua, es bonito, a mí me gusta la pesca por muchas cosas y lo que más me gusta es cuando gano buena plata, que es lo que más me gusta.

En cuanto a Mario Zamora, igualmente se puede apreciar una importante capacidad de apreciación paisajística:

Bueno, digamos, cerca del estero, digamos, hay mucho paisaje de aves, de especies en el manglar, verdad, y allá [mar adentro], digamos, es muy diferente, por ejemplo, acá se maneja lo que son los pelícanos al lado del estero, allá en alta mar son otras especies que vienen de otras latitudes, por ejemplo, hay unos tipos de pato que a veces vienen del norte y van en transición, verdad, entonces uno a veces se los topa también. Hay otro tipo de pájaro, no me acuerdo ahorita, que también hay mucho en Galápagos que son las zonas más frías, entonces a veces corrientes de viento se los traen para estos lados. Una vez tuvimos la oportunidad de ver un, cómo se llama, una foca en tiempos, digamos, de que habían aguas muy frías, tal vez había algún tipo de frente frío, en aquel entonces que las aguas estaban sumamente heladas logramos ver una foca en aguas de Costa Rica.

${ }^{13}$ En Nuevos ejes de acumulación y naturaleza: el caso del turismo, le he dedicado un apartado a la reflexión sobre el ocio en relación con el trabajo (Cordero Ulate, 2006, pp. 24-30).

${ }^{14}$ Priende: enciende. 
A continuación reproduzco en extenso una parte del relato de Mario Zamora, pues ilustra con claridad un clímax paisajístico cuando se juntan abundancia pesquera y paisaje. El paisaje en su máxima expresión es cuando al encontrar un banco de peces estos logran ser atrapados en la red:

algunas veces podías ver delfines, algunas veces podías ver ballenas, podías ver saltando a los marlín, los velas, los dorados cazando los peces voladores detrás de ellos, manchas de atunes, por ejemplo, tuvimos la suerte de tener en varias ocasiones nos encontramos, por ejemplo, un palo, un trozo de madera, digamos, con una gran diversidad de especies alrededor, por ejemplo, cuando un palo de esos está mucho tiempo en el mar se va formando una cadena alimenticia, debajo del palo hay peces pequeñitos que van con la corriente, otros pececitos más grandes llegan a tratar de comerse a estos otros, a veces encontrábamos un palo de estos y era como asegurarse el viaje de siete días y traer el pescado en dos días porque alrededor del palo andaban tiburones, andaban marlín, andaba mucho dorado y más bien uno lo pescaba a la cuerda, no teníamos necesidad de echar el equipo de pesca, la línea, sino que lo que hacíamos era que amarrábamos el palo pegado a la embarcación lo amarrábamos, verdad, para que la corriente junto con el barco fuera jalando la mancha de pescado y entonces nosotros ahí con carnada empezábamos a pescar, entonces habían unos momentos en el que el pescado tal vez no quería comer por tiempo entonces le dábamos tiempo mientras tanto así nos daba tiempo a nosotros de acomodar el pescado y luego seguíamos pescando, esas eran las cosas que nos llamaba mucho la atención, que habían muchas especies.

Este paisaje, obviamente hermoso por la belleza de la diversidad de peces "jugando" en el mar, revoleteando alrededor de un tronco que pudo haber sido arrastrado desde tierra firme, cualquier turista lo desearía. De igual forma, un artista pictórico especializado en estos temas hallaría abundante material. Paradójicamente, al paisaje de la abundancia marina se le encuentra no con el propósito declarado de buscarlo y disfrutarlo, sino por andar trabajando en la pesca. El paisaje es accidental a la actividad central, o sea, la pesca, pero también el pescador la disfruta paisajísticamente, no solo vive del trabajo. Tiene capacidad de desdoblamiento paisajístico, por decirlo de algún modo. Disfruta del paisaje cuando lo rememora, cuando lo relata, como en este caso. Es capaz de reproducir la imagen paisajística de manera verbal.

El lenguaje de Abuelo es menos abundante en lo paisajístico, pero las pocas palabras para referirlo resultan contundentes. Véase un ejemplo de diálogo paisajístico que tuve con él: 
Allen Cordero: ¿Y de los lugares de pesca a los que usted iba, había uno que le gustaba más o todos eran iguales?

Abuelo: Para mí todos iguales, pero lo pesca es más bonita cuando fuimos a Ecuador. Allen Cordero: ¿Por qué le gustó ese viaje?

Abuelo: Porque son seis días de carrera para llegar hasta allá, en la noche pescábamos calamar, calamar grande, la carnada bien preparada para después trazar la línea... [Pero a partir de aquí Abuelo empezó a relatar un conflicto que tuvo con un compañero y que casi llega a un asesinato, es decir, cuando el informante casi mata a un compañero que lo estaba acosando. Más adelante cuando retomé el interrogatorio sobre por qué le gustó Ecuador me dijo:] Por el agua tranquila, fresquita a estas horas hace un frío, viera qué frío.

Allen Cordero: ¿Cómo es el paisaje?

Abuelo: ¡Ahh, lindo lindo lindo!

Allen Cordero: ¿Qué se puede ver?

Abuelo: No, tierra no se ve.

Allen Cordero: ¿Pero qué se ve, qué cosas se pueden observar, digamos?

Abuelo: Ah, calamares grandes, pescado grande, marlín blanco.

Allen Cordero: ¿Cómo se puede observar los calamares?

Abuelo: Ah, en la noche.

Allen Cordero: ¿Cómo se ven, de qué color?

Abuelo: Cafecito, de un café color oscuro claro, cuando hay luna no se ven, es en la noche oscura porque el calamar... los picos bien arriba está usted mirando mirando, por más que se estire los tentáculos, no se despegan.

Allen Cordero: ¿Eso le gustaba?

Abuelo: ¡Ah, sí! Tener como 50 calamares en carnada, 300, 400... si queda muy grande lo partían en dos o entero.

Allen Cordero: ¿Ah, se usaba como para carnada?

Abuelo: Para carnada sí.

Pueden advertirse las expresiones paisajísticas tales como lindo, peces diversos y, sobre todo, la bella imagen del calamar con sus tentáculos de luz en el mar oscuro, para de inmediato relacionarlo con su función como carnada. 
El paisaje marino poético y apacible tiene su otro lado, agitado, oscuro y violento, o sea, cuando hay mal tiempo. Los pescadores piensan que esta constituye la parte adversa y difícil de su trabajo. Dependiendo de si es simplemente un temporal o una tormenta, la gradación problemática puede pasar de la incomodidad a la pesadilla ambiental, por tanto, paisajística. En el relato de Esparza pueden apreciarse estas gradaciones de adversidades:

El mar usted topa con suerte cuando está mansito a veces no puede ni comer uno, se apean unos tiempos tiene que estar con el plato así y el vaso prensado pa' poder comer porque esos barcos ni mesa tienen y aunque tuvieran usted pone el plato y allá va a dar porque hay unos tiempos bravísimos, unos aguaceros que hasta se va de lado el barco, es duro, es duro, y hay que trabajar así bajo una rayería y aguacero y hay que trabajar así porque no crea que usted sale hasta allá y el mar es mansito en una embarcación llevándola suave como decimos nosotros y no, son unos tiempos que usted no puede estar ni acostado porque lo quieren sacar de la cama, son camarotes no son camas, lo quiere sacar de la cama el mal tiempo, es duro no puede comer usted ni tranquilo, hermano. Y después para dar del cuerpo sus necesidades son pocos los barcos que tienen servicio, qué es lo que hay que hacer, guindarse de la borda en cuclillas, ahí guindado, y para venir aquí tal vez y no ganarse nada, no, no, si es duro, este trabajo es duro, después, digamos, usted tiene tres meses sin ver a su familia.

En el caso de Mario Zamora, su imagen combina firmamento oscuro con encomendarse a Dios. Curiosamente, esta relación de mar embravecido y lo sublime -claro está, siempre y cuando se esté a salvo- ya había sido establecida por Kant en su Crítica del juicio:

Rocas audazmente colgadas y, por decirlo así, amenazadoras, nubes de tormenta que se amontonan en el cielo y se adelantan con rayos y con truenos, volcanes en todo su poder devastador, huracanes que van dejando tras sí desolación, el océano sin límites rugiendo de ira, una cascada profunda en un río poderoso, etc., reducen nuestra facultad de resistir a una insignificante pequeñez, comparada con su fuerza. Pero su aspecto es tanto más atractivo cuanto más temible, con tal de que nos encontremos nosotros en lugar seguro, y llamamos gustosos sublimes esos objetos porque elevan las facultades del alma de su término medio ordinario y nos hacen descubrir en nosotros una facultad de resistencia de una especie total distinta, que nos da valor para poder medirnos con el todo-poder aparente de la naturaleza [Kant, 1977, pp. 163-164]. 
Y aquí está parte del relato de Mario Zamora:

cuando había mal tiempo en ese entonces que nosotros salíamos a pescar siempre habían dos cosas en contra, una era cuando estábamos en tiempo de invierno que eran las lluvias torrenciales y los malos tiempos que habían, no es como ahora que uno está informado varios días antes de que va a haber una tormenta, en aquel entonces uno salía como uno dice a "agache y machete", entonces cuando se te ponía oscuro el firmamento entonces uno más que todo se encomendaba a Dios para que lo protegiera porque en ese entonces la comunicación era muy escasa, digamos, esos eran temores que uno manejaba y otra cosa que también era en verano, en verano estaban los vientos del norte, los vientos alisios que siempre revientan en la llegada del verano, entonces en ese momento los vientos eran demasiado fuertes, todo eso ha ido cambiando, de hecho que estos últimos años los vientos alisios que uno percibía acá, digamos, incluso aquí en Puntarenas son más débiles, no son como los de antes, antes...

\section{Conclusión}

Es evidente, prácticamente obvio, que los hermosos relatos de estos pescadores que han dado cuerpo a esta investigación se inscriben en la historia del modo de producción predominante en Costa Rica y en particular en Puntarenas. El aspecto que aquí se ha ilustrado es el de, por decirlo de alguna manera, la trágica historia de la pesca. Puede sonar un poco fuerte o alarmista el adjetivo de "trágica" para caracterizar lo que ha ocurrido con la pesca, pero, como se ha expuesto, se pasó de la abundancia mítica a la triste escasez; este ha constituido el eje central de las descripciones socioeconómicas de nuestros informantes. Contar cómo era la pesca en sus tiempos de infancia y adolescencia para luego señalar qué ha quedado de ello en la actualidad.

Los pescadores han ilustrado con su información y razonamientos las causas de este agotamiento, que no son otras que las del progreso, las del avance técnico, las del crecimiento de un mercado y, por ende, la mercantilización crecientemente capitalista del recurso pesquero; el tamaño de los barcos, las técnicas de captura, los sistemas de refrigeración, las inmensas y apretadas redes; todo ello ha generado por desgracia un panorama preocupante y hasta desolador. 
En palabras que hemos utilizado en la introducción teórica a este texto: es el modo de producción haciéndose. O bien, la articulación concreta de ejes de acumulación, que también puede ser entendida como "formación económicosocial”. Se ha pasado de un modo de organización artesanal de la pesca a uno de producción capitalista, dominado por flotillas de capital nacional y transnacional. Los pescadores artesanales no desaparecen del todo, pero se encuentran viviendo casi al margen del proceso de acumulación. Algunos de ellos, al no tener más alternativa, sucumben frente a las ofertas del narco, lo cual es perfectamente entendible (si algunas de las personas más respetables del país, incluyendo en primer lugar a los encargados del orden de la seguridad nacional e internacional, estuvieran en el lugar de estos pescadores, quizás harían lo mismo).

El paisaje que se ha ilustrado es obviamente el marino, una mezcla de puerto con mar. El agua en sus inmensidades y riquezas alimenticias. Los primeros paisajes relatados eran de algún modo paisajes de costa desde un mar cercano, es decir, paisajes desde las lanchas de madera divisando las islas del golfo y la costa de Puntarenas. A medida que la pesca ha escaseado, el agua ha predominado sobre la tierra. Las salidas de pesca son más alejadas, allá donde todavía, si la suerte los favorece, pueden hallar peces. Allá cerca de la Isla del Coco, o bien, mares lejanos, presumiblemente cercanos a los mares territoriales de otros países de la región centroamericana o de Ecuador y México. Las especies de esos mares lejanos se han ido agregando a los primeros inventarios elementales de la pesca artesanal. Por ejemplo, la lista de especies de camarones ha aumentado. Pero la sobreexplotación ha llevado a una nueva escasez. Lograr pescar se hace cada vez más un asunto de nuevas tecnologías, barcos de mayor calado y mucho capital. Los pescadores artesanales son marginados de la formación socioeconómica, la cual presenta un perfil más directamente acumulativo.

De alguna forma, el paisaje para estos pescadores se ha hecho recuerdo. Hasta cierto punto, es un paisaje nostálgico. Se lo ha llevado el modo de producción. Los años mozos también se han ido, aquellos de la abundancia de peces, que significaban venir con los bolsillos llenos, para derrochar plata y juventud en las alegres cantinas y salones de baile. Esa es la gran añoranza de nuestros informantes. 
Asimismo, resulta prácticamente obvio señalar que los pescadores han modelado el paisaje con su trabajo. En sus primeros tiempos de pescadores artesanales lo modelaban de manera más directa, pues ellos mismos tomaban las decisiones de viaje, las técnicas a emplear, el tipo de embarcaciones y demás. En la medida en que el modo de producción capitalista se ha entronizado en la pesca, siguen construyendo el paisaje pero de forma subordinada como asalariados contratados, por lo general a destajo. Es distinto paisajísticamente pescar cerca de la costa encontrando abundancia de peces y venderlos uno mismo en el mercado o a quien se acerque a comprarlos, a estar esperando en el Parque Mora y Cañas a ver qué empresario los contrata para una salida de alta mar.

Apreciar el paisaje constituye una suerte de mirada en perspectiva. La palabra paisaje no dice mucho a estos pescadores. La palabra trabajo sí los convoca. El paisaje entra articulado con el trabajo, siendo este último la categoría predominante.

Dicho de otro modo, puede pensarse que todo lo que nos platican estos pescadores sobre el trabajo es construcción del paisaje, pero no a partir de la palabra paisaje, sino de otras como trabajo, vida familiar, diversión, recuerdos del barrio, etcétera.

Lo anterior no implica que la palabra paisaje no le diga nada a los pescadores. Lo que planteo es que no es sencillo articular una conversación puramente paisajística con ellos. Quizás por el elemento geográfico del mar, por cuanto en sí mismo expande la perspectiva que lleva a mirar con amplitud y en diferentes direcciones, algunos pescadores pueden hablar de esa visión general, por ejemplo, el mar iluminado por las estrellas o por un barco atunero. Sin embargo, pueden referirse con más propiedad y detalle a los peces, a la belleza marina, casi directamente relacionado con lo que estos elementos significan para su vida material, para su economía.

El desdoblamiento contemplativo del paisaje sí se da en estos pescadores, pero de manera puntual y cuando se les "ayuda” a pensar paisajísticamente. Por supuesto, "ayudar” no supone imponerles los paisajes sino preguntarles en un sentido socrático para que ese elemento contemplativo emerja, aunque sea atropellado por las explicables urgencias de la vida. 


\section{Fuentes consultadas}

Bertaux, D. (2005). Los relatos de vida. Perspectiva etnosociológica [(1997). Les récits de vie. Nathan-Université]. Barcelona: Edicions Bellaterra.

Chong, L. (1 ${ }^{\circ}$ de enero de 1992). Costa Rica: mejor aprovechamiento de los recursos marinos. Taiwán hoy. Recuperado de http://taiwanhoy.nat. gov.tw/fp.asp? xItem $=73588 \&$ ctNode $=1544$ [2014, 28 de febrero].

Cordero Ulate, A. (2006). Nuevos ejes de acumulación y naturaleza: el caso del turismo. Buenos Aires: Consejo Latinoamericano de Ciencias Sociales.

Cordero Ulate, A. (2014). Paisajes y relatos de vida. Apuntes para la interpretación de los paisajes socio-culturales con mención a Puntarenas y Limón (centro) en Costa Rica. Teoría y Praxis, 2014, 16, 9-31.

Hegel, G. W. F. (1983). Estética (8 ts.) [tomada de la $2^{\text {a }}$ ed. alemana de 1842]. Buenos Aires: Ediciones Siglo Veinte.

Kant, I. (1977). Crítica del juicio. México: Espasa-Calpe/Mexicana.

Li Chan, E. (2013). Sincretismo lingüístico lexicográfico culinario gastronómico en el dialecto "puntanerense". InterSedes, XIV(28), 234-252. Recuperado de http://revistas.ucr.ac.cr/index.php/intersedes/article/ viewFile/12130/11416 [2014, 28 de febrero].

Nogué, J. (ed.). (2007). La construcción social del paisaje. Madrid: Biblioteca Nueva.

Roger, A. (2007). Breve tratado del paisaje [(1997). Court traité du paysage. París: Éditions Gallimard]. Madrid: Biblioteca Nueva.

Watsuji, T. (2006). Antropología del paisaje, climas y culturas y religiones. Salamanca: Ediciones Sígueme. 